\title{
STUDIES ON THE BACTERICIDAL PROPERTIES OF THE SYNOVIAL FLUID ${ }^{1}$
}

\author{
By PAUL F. DE GARA \\ (From the Department of Pathology, Cornell University Medical College, New York City)
}

(Received for publication June 24, 1942)

Studies on normal synovial fluid and on joint effusions under pathological conditions háve been reported (1, 2). In 1919, Labor and von Balogh (3) detected antibodies in the joint cavity during inflammations of the joints. Their results have been confirmed (4 to 6). Positive gonorrheal complement fixations and positive Wassermann reactions in joint fluids have also been reported (1).

The bactericidal activity of various body fluids has been repeatedly investigated $(5,7$ to 9$)$, but the only communication of similar studies on synovial fluid was made by Spink and Keefer (10). These authors studied the killing power for gonococci of 44 synovial fluids from 18 patients with gonorrheal and from 13 patients with non-gonorrheal arthritis. Fluids which contained living gonococci and those from patients with nongonorrheal arthritis were not bactericidal for gonococci. Sterile synovial fluids from patients with gonorrheal arthritis killed the homologous strain of gonococcus. Their bactericidal power was the same or slightly weaker than that of the blood.

According to Collins (11), "the joint fluid in rheumatoid arthritis, on account of its content of polymorphs, is highly bactericidal." Sweetapple (12) pointed out that "synovial fluid is strongly antibacterial while fresh, but excellent pabulum for bacteria when stale." Neither author offered experimental proof for these statements. In rabbits with experimental streptococcal arthritis, synovial fluid obtained more than 3 to 6 weeks after the infection is usually sterile (13).

The object in undertaking the present investigation was to study the bactericidal activity for gram-positive cocci and gram-negative bacteria of the synovial fluid of patients with rheumatoid arthritis and other joint diseases.

1 Aided by grants from The John and Mary R. Markle Foundation, The Ophthalmological Foundation, and The Dazian Foundation for Medical Research.
It was thought that the detection of a "specific" bactericidal activity for hemolytic streptococci in the synovial effusions from patients with rheumatoid arthritis would support the theory of the streptococcus etiology of this disease. Attempts to isolate a specific microorganism from the synovial fluid in rheumatoid arthritis have been unsuccessful in a high percentage (14), but there is inferential evidence that hemolytic streptococci may be of etiological significance in this disease.

Whenever possible, oxalated blood plasma was tested for its bactericidal activity simultaneously with the joint fluid of the same patient.

In addition, cultures were made and the complement content, as well as the agglutinin titre for streptococci and for $E$. coli; determined. Certain physicochemical and cytological properties of the synovial fluid were also studied.

\section{MATERIALS AND METHODS}

Synovial fluid was obtained by aseptic puncture of the affected joint, usually the knee, of $\mathbf{4 0}$ patients with rheumatoid arthritis or other joint diseases.

Cultures for the bactericidal test. Ten-fold dilutions (up to $10^{3}$ ) of 18-hour broth cultures of a beta hemolytic streptococcus (Strain AB 13) and an Escherichia coli were made in broth. The number of organisms in the last dilutions was determined by making pour plates with 0.1 cc. portions of those dilutions. The number of colonies grown in the $10^{\circ}$ and $10^{\circ}$ dilutions usually ranged between 20 and 200 . These dilutions were used in the experiments. Similar dilutions of overnight broth cultures of 2 other strains of beta hemolytic streptococci, a hemolytic staphylococcus aureus, a Type I pneumococcus, another strain of $E$. coli, and an Eberthella typhi ( $\mathrm{H}$ and $O$ strains) were used in some of the experiments.

Bactericidal test. One-half cc. portions of the materials to be tested were mixed in sterile $10 \times 100 \mathrm{~mm}$. pyrex glass tubes with $0.1 \mathrm{cc}$. of suitable, freshly diluted broth cultures of the microorganisms. The tubes were sealed and fastened to a square box on a rotating machine of the type described by Todd (15). After rotation for 24 hours, at $37.5^{\circ}$ C., at 8 to 10 r.p.m., 0.3 cc. of the contents of the tubes was plated out with agar, and 0.1 cc. was transferred into tubes of broth. Colony counts were made after 24 and 48 hours. If the rotation time was prolonged to 48 hours, the results did not 
change, but if it was reduced to only 6 hours, frequently the microorganisms were not killed.

In about one-half of the experiments, the mixtures were rotated in sterile $20 \times 70 \mathrm{~mm}$. vials, closed with a sterile rubber cap through which a sterile injection needle with a sterile cotton plug had been inserted. Sterile tuberculin syringes were used to fill the vials and to withdraw the contents after rotation. The "open" vials offer the following advantages: (1) The mixtures are tested under aerobic conditions, (2) the process of sealing of the tubes is eliminated, and (3) the vials can be used repeatedly.

The results with sealed tubes and open vials were equivalent in all the experiments with $E$. coli. In some experiments with streptococci in broth, however, fewer colonies developed on agar from the "open" vials than from sealed tubes.

Other examinations of the fluids. Cultures were made on liquid and solid media. Complement was titrated and agglutinin titres for streptococci and for $E$. coli were determined by the usual methods.

The mucin content was examined by the qualitative "sac and tube" test (1). The relative viscosity was estimated with Ostwald's viscosimeter (16). The specific gravity was determined by the drop method (17). The hydrogen ion concentration at the beginning of the experiment was determined by the bicolor method (18). For cytological studies, total and differential cell counts, and Giemsa and Wright stains, were made.

\section{RESULTS}

The bactericidal properties of synovial effusions for hemolytic streptococci and $E$. coli, in relation to the type of joint disease, are shown in Table I. Thirty-nine fluids were obtained from the knee joint and one from an elbow joint.

Bactericidal properties for hemolytic streptococci were detected in 4 of 37 fluids (10.8 per cent), for $E$. coli, in 34 of 39 fluids (87.1 per cent). Bactericidal properties for hemolytic staphylococci and for Type I pneumococci were absent in 6 fluids from patients with infectious and rheumatoid arthritis, and in 4 fluids from those with non-infectious arthritis. These fluids were not streptococcidal.

A strong bactericidal power for $E$. typhi was detected in 10 fluids which also killed $E$. coli.

Simultaneous studies of the bactericidal activity of the synovial fluid and oxalated blood plasma were made with materials from 15 patients. ${ }^{2}$ The results are given in Table II.

Three synovial fluids killed streptococci and 6 other effusions were bactericidal for $E$. coli, but the blood of the same patients did not kill streptococci or $E$. coli, respectively. In one instance, the blood plasma, but not the synovial fluid, was bactericidal. There was no difference in the bac-

2 It should be noted that the bactericidal activities of oxalated blood plasma were compared with those of native synovial fluid.

TABLE I

Bactericidal properties for hemolytic streptococci and Escherichia coli of human synovial fluid obtained from patients with various joint diseases

\begin{tabular}{|c|c|c|c|c|c|}
\hline \multirow[b]{2}{*}{ Lesion of joint } & \multicolumn{5}{|c|}{ Synovial fluids } \\
\hline & $\begin{array}{l}\text { Number } \\
\text { examined }\end{array}$ & $\begin{array}{l}\text { Number which were } \\
\text { bactericidal for } \\
\text { streptococci }\end{array}$ & $\begin{array}{l}\text { Number which were } \\
\text { non-bactericidal } \\
\text { for streptococci }\end{array}$ & $\begin{array}{c}\text { Number which were } \\
\text { bactericidal for } \\
\text { E. coli }\end{array}$ & $\begin{array}{l}\text { Number which were } \\
\text { non-bactericidal } \\
\text { for } E \text {. coli }\end{array}$ \\
\hline $\begin{array}{l}\text { (A) Infectious and rheumatoid arthritis } \\
\text { (a) Non-specific infectious...... } \\
\text { (b) Gonorrheal } \ldots \ldots \ldots \ldots \ldots \ldots \ldots \\
\text { (c) Syphilitic } \ldots \ldots \ldots \ldots \ldots \ldots \\
\text { (d) Rheumatoid* } \ldots \ldots \ldots \ldots \ldots \ldots\end{array}$ & $\begin{array}{r}2 \\
1 \\
2 \\
10\end{array}$ & $\begin{array}{l}1 \\
2\end{array}$ & $\begin{array}{l}1 \\
1 \\
2 \\
7\end{array}$ & $\begin{array}{l}2 \\
1 \\
2 \\
7\end{array}$ & 3 \\
\hline Total (A).............. & 15 & 3 & 11 & 12 & 3 \\
\hline $\begin{array}{l}\text { (B) Non-infectious arthritis } \\
\text { (e) Intermittent hydroarthrosis. } \\
\text { (f) Traumatic } \ldots \ldots \ldots \ldots \ldots \ldots \ldots \\
\text { (g) Hypertrophic } \ldots \ldots \ldots \ldots \ldots \ldots\end{array}$ & $\begin{array}{r}2 \\
6 \\
12\end{array}$ & 1 & $\begin{array}{r}1 \\
6 \\
12\end{array}$ & $\begin{array}{r}2 \\
5 \\
11\end{array}$ & $\begin{array}{l}1 \\
1\end{array}$ \\
\hline Total (B) $\ldots \ldots \ldots \ldots \ldots$ & 20 & 1 & 19 & 18 & 2 \\
\hline (C) Of unknown origin $\nmid \ldots \ldots \ldots \ldots$ & 5 & & 3 & 4 & \\
\hline Total $(\mathbf{A}+\mathbf{B}+\mathbf{C}) \ldots \ldots \ldots$ & 40 & 4 (10.8 per cent) & 33 & 34 (87.1 per cent) & 5 \\
\hline
\end{tabular}

* One specimen was not tested for streptococci.

$\dagger$ Two specimens were not tested for streptococci, a third was not tested for $E$. coli. 
TABLE II

Comparison of bactericidal properties for hemolytic streptococci and Escherichia coli in synovial fluid and blood plasma of 15 patients with various joint diseases

\begin{tabular}{|c|c|c|c|c|c|c|c|c|}
\hline \multirow[b]{2}{*}{ Lesion of joint } & \multirow[b]{2}{*}{$\begin{array}{c}\text { Total } \\
\text { number } \\
\text { of cases } \\
\text { examined }\end{array}$} & \multicolumn{7}{|c|}{ Number of cases with } \\
\hline & & $\begin{array}{c}\text { Fluid and } \\
\text { plasma } \\
\text { bactericidal } \\
\text { for strep- } \\
\text { tococcus }\end{array}$ & $\begin{array}{l}\text { Fluid only } \\
\text { bactericidal } \\
\text { for strep- } \\
\text { tococcus }\end{array}$ & $\begin{array}{l}\text { Fluid and } \\
\text { plasma non- } \\
\text { bactericidal } \\
\text { for strep- } \\
\text { tococcus }\end{array}$ & $\begin{array}{l}\text { Fluid and } \\
\text { plasma } \\
\text { bactericidal } \\
\text { for } E \text {. coli }\end{array}$ & $\begin{array}{l}\text { Fluid only } \\
\text { bactericidal } \\
\text { for } E \text {. coli }\end{array}$ & $\begin{array}{l}\text { Plasma only } \\
\text { bactericidal } \\
\text { for } E \text {. coli }\end{array}$ & $\begin{array}{l}\text { Fluid and } \\
\text { plasma non- } \\
\text { bactericidal } \\
\text { for } E \text {. coli }\end{array}$ \\
\hline 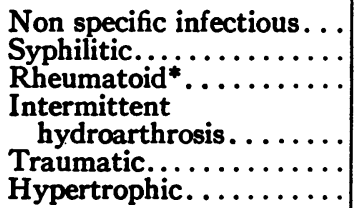 & $\begin{array}{l}1 \\
2 \\
6 \\
2 \\
1 \\
3\end{array}$ & 1 & $\begin{array}{l}1 \\
1 \\
1\end{array}$ & $\begin{array}{l}2 \\
3 \\
1 \\
1 \\
3\end{array}$ & $\begin{array}{l}1 \\
3 \\
2 \\
1\end{array}$ & $\begin{array}{l}2 \\
1 \\
1 \\
2\end{array}$ & 1 & 1 \\
\hline Total............ & 15 & 1 & 3 & 10 & 7 & 6 & 1 & 1 \\
\hline
\end{tabular}

* One specimen was not tested for streptococci.

tericidal properties of blood plasma and synovial fluid of 11 patients when tested with streptococci, and of 8 , when tested with $E$. coli.

The effect of undiluted and of diluted synovial fluid on increasing concentrations of $E$. coli is presented in Table III.

TABLE III

Effect of dilution of synovial fluid on bactericidal properties for various concentrations of Escherichia coli

\begin{tabular}{l|c|c|c|c}
\hline \multirow{2}{*}{$\begin{array}{c}\text { Dilution of } \\
\text { culture }\end{array}$} & \multicolumn{4}{|c}{ Number of colonies } \\
\cline { 2 - 5 } & $\begin{array}{c}\text { Synovial fluid } \\
\text { undiluted }\end{array}$ & $\begin{array}{c}\text { Synovial } \\
\text { fuid } \\
1: 5\end{array}$ & $\begin{array}{c}\text { Synovial } \\
\text { fluid } \\
1: 10\end{array}$ & Broth \\
\hline $10^{2}$ & $\infty$ & - & - & $\infty$ \\
$10^{4}$ & 1000 & $\infty$ & - & $\infty$ \\
$10^{6}$ & 9 & $\infty$ & $\infty$ & $\infty$ \\
$10^{6}$ & 0 & 0 & $\infty$ & $\infty$ \\
\hline $10^{6 *}$ & 90 & 90 & 90 & 90 \\
\hline
\end{tabular}

* Number of organisms inoculated into $10^{6}$ dilution.

$\infty$ = innumerable colonies.

- $=$ no test made.

Five-fold dilutions in broth of synovial fluid did not reduce the killing power for small amounts of $E$. coli. No bactericidal activity was present in ten-fold diluted synovial fluid. With increasing concentrations of $E$. coli, the bactericidal properties of the synovial fluid diminished almost quantitatively. Similar observations were made on the bactericidal activity for streptococci of the few fluids which could be tested.

The influence of inactivation by heat on the killing power of synovial fluid for $E$. coli is given in Table IV.
TABLE IV

Effect of heating of synovial fuid on bactericidal properties for Escherichia coli

\begin{tabular}{|c|c|c|c|}
\hline \multirow{2}{*}{ Medium } & \multicolumn{3}{|c|}{$\begin{array}{c}\text { Number of colonies after rotation } \\
\text { at } 37.5^{\circ} \mathrm{C} \text {. }\end{array}$} \\
\hline & Fluid & Fluid & Fluid \\
\hline 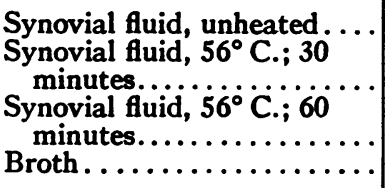 & $\begin{array}{l}0 \\
0\end{array}$ & $\begin{array}{r}0 \\
25 \\
550 \\
\infty\end{array}$ & $\begin{array}{l}0 \\
0 \text { (48 hours) } \\
8 \text { (96 hours) }\end{array}$ \\
\hline
\end{tabular}

$\infty=$ innumerable colonies.

$-=$ no test made.

Inactivation in a water bath at $56^{\circ} \mathrm{C}$. for 30 minutes did not alter the bactericidal activity for $E$. coli of one fluid, but diminished that of 2 other fluids. Heating at $56^{\circ} \mathrm{C}$. for 60 minutes caused a further reduction, but not a complete destruction, of the bactericidal properties of fluid 2 . Retardation of bacterial growth by inactivated synovial fluid was observed in specimen 3 . Inactivation at $56^{\circ} \mathrm{C}$. for 30 minutes completely destroyed the bactericidal activity for streptococci of the few fluids which could be tested.

Eighteen synovial fluids were frozen and kept for 6 months in dry ice at approximately $-50^{\circ}$ C. The bactericidal activity for $E$. coli was retested frequently. It was found almost unaltered after 180 days of storage. The bactericidal properties of 2 fluids for streptococci were completely lost after storage in dry ice for 3 and 12 days, respectively. 
Bacteriological cultures of all fluids used in this study were sterile.

Complement titrations were made on 20 specimens of fresh synovial fluid and of effusions stored in dry ice for periods up to 75 days. The titre of 14 fluids varied between 0.025 and $0.1 \mathrm{cc}$. (average $0.05 \mathrm{cc}$.), while that of 6 fluids was above $0.1 \mathrm{cc}$. The complement titre of stored fluids gradually decreased within 2 months; the bactericidal activity for $E$. coli, however, remained practically unaltered for at least 6 months. The complement titre was very low in 3 of the 5 fluids not bactericidal for $E$. coli. The titre of the other 2 fluids was not tested. The streptococcidal fluids had a normal complement titre.

Agglutinins for streptococci were found in 2 synovial fluids in final dilutions of $1: 40$; these fluids were not streptococcidal. No agglutinins for streptococci were detected in the other fluids. The agglutination reactions with $E$. coli were always negative.

The mucin reaction was always positive. The relative viscosity of the fluids varied between 2.9 and 39.1, the specific gravity, between 1.018 and 1.026 , and the hydrogen ion concentration at the beginning of the experiment, between $\mathrm{pH} 7.4$ and $\mathrm{pH}$ 8.2.

Cytological examinations revealed wide variations in total and differential cell count as reported by previous authors (1). The lowest total cell count was 595 per c.mm., the highest 51,300 per c.mm.

There was no relation between viscosity, specific gravity, hydrogen ion concentration, or cytology of the synovial fluids and their bactericidal properties for hemolytic streptococci or $E$. coli.

\section{COMMENT}

Most of the synovial fluids from various joint diseases were strongly bactericidal for $E$. coli and E. typhi. This activity was closely related to the complement content of the synovial fluid, but heating at $56^{\circ} \mathrm{C}$. for 30 to 60 minutes did not completely destroy the bactericidal properties. It has been shown (19) that the third and fourth components of complement require a temperature of $62^{\circ}$ to $65^{\circ} \mathrm{C}$. for inactivation. No experiments with inactivation at this higher temperature were done in this study. It seems con- ceivable that the heat-stabile components of the complement may be responsible for the bactericidal activity of "inactivated" synovial fluid.

The bactericidal activity for gonococci of gonorrheal synovial fluid was thought to be due to specific antibodies (10). According to Bauer (20), however, "blood from non-gonorrheal patients may show the same variations in bacterial killing power to various gonococcal strains as do patients with acute or chronic gonorrhea." In this study, no agglutinins for $E$. coli or $E$. typhi were found in the fluids which killed these organisms. Bactericidal activity for these microorganisms was detected in the synovial fluid from patients with a variety of joint diseases. It is unlikely that specific antibodies were responsible for this activity.

There is evidence (21) that strains of streptococci vary in susceptibility to bactericidal action of serum and that there is not a good correlation between in vivo evidence of streptococcidal power of patients' blood and in vitro activity of sera. Variations in hydrogen ion concentration and in oxidation-reduction potential play important parts in inhibiting the streptococcidal activity of serum (22). No significant variation in susceptibility was noted in the 3 strains used in our experiments, but this does not mean that other strains of greater susceptibility would not have been encountered if a greater number of strains had been tested with synovial fluid, or that wider ranges of hydrogen ion concentration and oxidation-reduction potential might not have brought to light more fluids with streptococcidal activity. However, there can be no question that streptococcidal activity cannot be as easily and regularly demonstrated as some previous reports indicated (11, 12). Even fluids with high leukocyte counts were devoid of streptococcidal activity.

Bactericidal properties for hemolytic streptococci were detected in 2 of 9 synovial fluids from patients with rheumatoid arthritis, and in 2 of 28 fluids from other joint diseases. These results do not justify the conclusion that streptococcidal antibodies are usually present in synovial effusions of patients with rheumatoid arthritis, or that their presence is specific for this disease.

From the studies of synovial effusions, it would appear that the bactericidal activities for grampositive cocci are distinctly different in nature 
from those for gram-negative bacteria. The bactericidal activity for gram-positive cocci may be related to the combined action of many phagocytic cells and antibodies. In our studies, evidence for this hypothesis was obtained from a few experiments on the synovial fluid of animals which had received intravenous or intra-articular injections of a sterile irritant or of living or killed hemolytic streptococci (23). All the human synovial fluids examined contained phagocytic cells but only a few effusions were streptococcidal. Thus it can be stated that most of the synovial fluids were practically free of streptococcidal antibodies. The bactericidal activity for gramnegative bacteria is closely related to the complement content of the synovial fluid and may, therefore, be expected to be present in effusions containing sufficient amounts of complement.

\section{SUMMARY}

The bactericidal properties of 40 sterile synovial effusions from patients with rheumatoid arthritis or other joint diseases were studied. Four of 37 synovial fluids (10.8 per cent) killed hemolytic streptococci, and 34 of 39 synovial fluids ( 87.1 per cent) were bactericidal for $E$. coli. The killing power of the synovial fluid usually was stronger than that of the oxalated blood plasma. Bactericidal properties for hemolytic streptococci were detected in only 2 of 9 synovial fluids in rheumatoid arthritis (22.2 per cent), and 2 of 28 synovial fluids in other joint diseases (7.1 per cent).

The bactericidal activity for $E$. coli, but not for hemolytic streptococci, was related to the complement content of the synovial fluid; it was not completely destroyed by heating at $56^{\circ} \mathrm{C}$. for 30 to 60 minutes, and remained almost unaltered for 6 months in frozen synovial fluid.

There was no relation between viscosity, specific gravity, hydrogen ion concentration at the beginning of the experiment, or cytology of human synovial effusions and their bactericidal activities for hemolytic streptococci or Escherichia coli.

The collaboration of members of the Medical Staff of the New York Hospital, of Drs. H. J. Jaffe and J. E. Blair, and of Miss F. A. Hallman of the Hospital for Joint Diseases in New York City, of Dr. C. Z. Garber of the New York Orthopedic Dispensary and Hospital, and of Dr. J. Freund, Otisville, N. Y., in securing the materials for this study, is gratefully acknowledged.

\section{BIBLIOGRAPHY}

1. Kling, D. H., The Synovial Membrane and the Synovial Fluid with Special Reference to Arthritis and Injuries of the Joints. Medical Press, Los Angeles, 1938. (With references.)

2a. Ropes, M. W., Bennett, G. A., and Bauer, W., The origin and nature of normal synovial fluid. J. Clin. Invest., 1939, 18, 351.

b. Bauer, W., Ropes, M. W., and Waine, H., The physiology of articular structures. Phys. Reviews, 1940, 20, 272.

c. Ropes, M. W., Coggeshall, H. C., and Bauer, W., The diagnostic value of synovial fluid examination. J. Clin. Invest., 1941, 20, 455.

3. Labor, M., and von Balogh, E., Zytologische und serologische Untersuchungen der Synovia im besonderen bei akuten Gelenksentzündungen. Wien. klin. Wchnschr., 1919, 32, 535.

4. Zia, S. H., The occurrence of dysentery and typhoid antibodies in joint and pleural exudates. Nat. M. J. China, 1931, 17, 302.

5. Hitchcock, C. H., and Swift, H. F., The agglutinating properties of exudates from patients with rheumatic fever. J. Clin. Invest., 1933, 12, 673.

6. Foshay, L., and Mayer, O. B., Viability of Bacterium tularense in human tissues. J. A. M. A., 1936, 106, 2141.

7. von Gara, P., Ueber die bactericiden Kräfte der Cerebrospinalflüssigkeit, sowie entzündlicher und nichtentzündlicher Ergüsse der Brust- und Bauchhöhle. Klin. Wchnschr., 1928, 7, 2386.

8. Finland, M., Immunological reactions of pneumonic pleural fluids. J. Exper. Med., 1932, 55, 169.

9: von Gara, P., and Frantz, O. B., Ueber die Bactericidie der Cerebrospinalflüssigkeit, sowie entzündlicher und nichtentzündlicher Ergüsse. Klin. Wchnschr., 1933, 12, 822.

10. Spink, W. W., and Keefer, C. S., Studies of gonococcal infection. III. A comparison of the bactericidal properties of the synovial fluid and blood in gonococcal arthritis. J. Clin. Invest., 1938, 17, 17.

11. Collins, D. H., Observations on the pathology of acute rheumatism and rheumatoid arthritis. Rheumat. Dis., 1939, 1, 38.

12. Sweetapple, H. A., Septic arthritis of the knee joint. M. J. Australia, 1939, 1, 542.

13. Cecil, R. L., Angevine, D. M., and Rothbard, S., Experimental arthritis in rabbits produced with streptococci and other organisms. Am. J. M. Sc., 1939, 198, 463.

14. Blair, J. E., and Hallman, F. A., Rheumatoid (atrophic) arthritis. Bacteriologic cultures of synovial fluid and of tissues. Arch. Int. Med., 1934, 53, 87. (With references.)

15. Todd, E. W., A method of measuring the increase or decrease of the population of haemolytic streptococci in blood. Brit. J. Exper. Path., 1927, 8, 1.

16. Hawk, P. B., and Bergeim, O., Practical Physiological Chemistry. P. Blakiston's Son and Co., Inc., Philadelphia, 1931. 10th edition. 
17. Kirkpatrick, J., and Kling, D. H., A simplified method for determination of the specific gravity of a few drops of urine. J. A. M. A., 1926, 87, 487.

18. Hastings, A. B., Sendroy, J., Jr., and Robson, W., Studies of acidosis. XXI. The colorimetric determination of the $\mathrm{pH}$ of urine. J. Biol. Chem., 1925, 65, 381.

19. Ecker, E. E., Pillemer, L., and Kuehn, A. O., Thermostability of heatstabile components of complement. Proc. Soc. Exper. Biol. and Med., 1940, 45, 115.

20. Bauer, W., The problem of rheumatism and arthritis. Review of American and English literature for 1938. Ann. Int. Med., 1940, 13, 1667.
21. Tillett, W. S., The bactericidal action of human serum on hemolytic streptococci. I. Observations made with serum from patients with acute infections and from normal individuals. II. Factors which influence the phenomenon in vitro. J. Exper. Med., 1937, 65, 147 and 163.

22. Tillett, W. S., and Stock, C. C., The bactericidal action of human serum on hemolytic streptococci. III. Studies concerning:(1) The significance of hydrogen ion concentration in relation to streptococcidal action of serum; (2) The effect of reducing agents on the phenomenon. J. Exper. Med., 1937, 66, 617.

23. de Gara, P. F., Unpublished observations. 